\section{"Mimicry" in Birds}

If Mr. Young will look at the fourth edition of Yarrell's "British Birds", he will find that the fact he mentions (ante, P. 486) has already attracted notice, for he will there read (vol. i. p. 616):-

"In places near Thetford, where the ringed plover is common, skylarks often imitate the note of that bird, making it part of their own song."

Magdalene College, Cambridge, April 19 ALFRED NEWTON

OUR starlings here, which are a numerous and accomplished colony, have acquired the following notes of other birds :- Curlew, red-shank, blackinird, thrush, magpie, swallow, swift, chaffinch, hotse sparrow, hedge sparrow. The most successful imitations are those of the curlew, red-shank (the note uttered by the latter on taking wing), and the swallow. I have several times this year been certain that I heard a swallow twittering on the house-top, and found that the note proceeded from a starling.

The jays also in this neighbourhood, which are very plentiful, are very able minics; the note of the carrion crow is abou their most successful effort.

Riding Mill-on-Tyue, April 22

\section{The Westinghouse Brake}

UNDYR the heading, "Notes," in NATURL, vol. xvii. p. I4O, there is a paragtaph describing the automatic brake of the Weitinghouse Brake Coupany, St. Stcphen's Palace Chambers, Westuminster, the latter jart of which refers to a ball which performs certain functions under clifferent circumstances. In a previoulis account in the Timcs, three balls are mentioned as being used in the experiment; it also states that severul sentleinen were investirating the mathematical principles under which these functions fel!. I lawe not seen any results of their work, neitlice is there nny comment upon it in NATURs. I therefore take cccasion to mention it, in order that if any accomt of it lass passed me, I may be informed of it, or that, if no results have appeared, this may lead to the subject being investigated by some of the mathematical correspondents of you esteemed paper.

G. O. K.

\section{Sound and Density}

Since velocity of sound does not vary with dinsicy (Baltour Stewart, (hap. IV., "Elenentary Physic.s"), would you kindly state the answer that should be given to the question, Why does sound travel quiclier in water and wood than in air, and what is the relation betwcen density and velocity of sound in wate'r, wood, air?

The Acadeiny, Montrose, April is

J. Cameron

[The velocity of sound depends on the ratio between the mass and the elasticity, and in air (to which P'rof. Stewart refers) it does not vary with the density of the air if its temperature only remain constant. In this case the denser the air the greater the mass, but the greater the elasticity in the samc proportion. The ratio between mass and elasticity is thus unaltered, and therefore the velocity remain; under these conditions the same.-ED.]

\section{OUR ASTRONOMICAL COLUMN}

THE TRANSIT OF VENUS IN I8S2. - In addition to independent calculations of the circumstances of this phenomenon, founded upon Le Verrier's tables of the sun and planet, to which reference has already been made in NATURE, we have to record the publication of two memoirs upon the same subject, the first by Herr Bruno Peter, who is attached to the Observatory at Leipsic, the second by Dr. Karl Friesach, of Graz, which has been received within the last week. As was to be expected where practised calculators are working upon the same data, the direct results from the tables are in very close accordance with those previously published; indeed the advantage of so many repetitions of such work is not very evident. The differences which the calculated times of the geocentric contacts exhibit are almost wholly due to the employment of different semi-diameters of sun and planet. Le Verrier suggested (¿imules, vol. vi. p. 40) that for the present the values to be employed should be respectively $958^{\prime \prime} \cdot 424$ and $8^{\prime \prime} \cdot 305$ for the mean clistance. Herr Peter has used $96 \mathrm{I}^{\prime \prime} \cdot 2 \mathrm{I}$ and $\mathrm{S}^{\prime \prime} \cdot 472$, and Dr. Friesach, $960^{\prime \prime} \circ \mathrm{O}$ and $8^{\prime \prime} \cdot 30 j$. Their results for Paris mean times of contacts and least distance of centres are subjoined :-

Transit of Vinzs, ISS2, Dicembir 6.

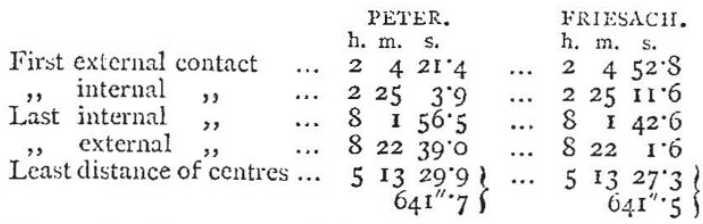

ENCKE'S COME'I IN I 878 .-Observers in the southern hemisphere may be reminded that this comet is likely to be a pretty conspicuous telescopic object in their evening siky, in the first days of August: Accorcling to Dr. von Asten's latest researches on the motion of this comet, the period of revolution at the last peribelion passage was $1200^{\circ} 8$ days, which, without taking any account of perturbations (not likely to be very material during the present revolution), would bring it again to periluelion on July 27. Mr. Tebbutt, of Windsor, N.S.W., has once found Encke's comet without assistance bejond his own calculations, but it will probably be Dr. von Asten's intention to furnish southern obscrvers with a reliable ephemeris commencing with August next. Observations will not be practicable before the peribelion passage, the comet being too near to the sun's place.

THE "BERLINER ASTRONOMISCHES JAHRLUCH" AND THI MANOR l'LANETS. - The volmme of this ephemeris for 1880 has just appeared under the joint editorship of Professors Förster and Tietjen. The general contents are similar to those of preceding volumes. The ephemeris of the moon is again transferred, with full acknowledgment from the Nautical Almanac, and a great amount of labour of computation is thereby saved, which is made to tell upon the specialty of the work, the preparation of ephemerides of the small planets as far as their orbits are sufficiently determined. The reader who may be in search of the elements of these bodies will find in this new volume of the Berliner Ja/rouch the most complete and reliable table yet in the hands of astronomers. It includes orbits of all the minor planets to No. 172, with the exception of No. 155, Scylla, for which the necessary materials for calculation are wanting; and while referring to Scylla, it may be remarked that the four observations on November 8, 9, 22, and 23, I875, cannot be represented by an elliptical orbit, which raises a suspicion that those of November 8 and 9 may belong to one planet, and those of November 22 and 23 to another, not, so far, recognised in the list. On examining the table of elements it is scen that No. 153, Hilda, has by far the longest period, while No. I49, Medusa, is credited with the shortest, according to the calculations of Prof. Tietjen. The observations of Medusa, however, extend over a period of eight days only, but they appear very exact, and it has happened that from a similar short interval of accurate observation, very close approximation to the true elements of an elliptical orbit has been attained; we may especially note the case of the shortperiod comet of De Vico in 1844: from eight days' very precise observations, M. Faye deduced an orbit which, as was pointed out by Prof. Brünnow, was almost identical with the result of his own elaborate investigation of the elements from the whole extent of observation. It is unfortunate that Hilda has escaped observation at the last opposition, since of all the small planets it is most desirable to keep this one in view, from the fact of its orbit allowing of a very much closer approach to the planet Jupiter than is possible in the case of any other. 